\title{
The Role of Tomohon Society's Local Wisdom in Developing Tolerance Attitudes
}

\author{
Theodorus Pangalila, Jeane Mantiri
}

\begin{abstract}
The problem of tolerance in Indonesia today is something that is warmly discussed. Issues and events leading to an atmosphere of intolerance are rampant in various regions in Indonesia. This is undoubtedly a severe threat to the sustainability of the country and the Indonesian people who have the motto of Unity in Diversity, which contains a broad meaning of diversity in diversity. The purpose of this research is to identify and photograph the local wisdom of the people of North Sulawesi, especially in the city of Tomohon which can be used as values in building an atmosphere of tolerance in the community. In this study, researchers chose to use a qualitative descriptive approach by collecting data through observation, interviews and documentation studies. In this study a qualitative approach is used because it fits the problems studied, and also because: (1) the approach in this study is more flexible, (2) can present data directly, the nature of the relationship between informants and researchers, (3) can adjust and sensitive to the phenomena faced in the field. The sources of data in this study are local government, religious leaders, forums for inter-religious harmony, traditional leaders, community leaders, and local communities and immigrants. This study found that tolerance in the community of the city of Tomohon was maintained because of the strong values contained in local wisdom.
\end{abstract}

\section{Index Terms: Local Wisdom, Tolerance, Society.}

\section{INTRODUCTION}

Pluralism is the fundamental essence of the Indonesian nation. In Bhinneka Tunggal Ika, which is the slogan of the Indonesian nation, there is a deep meaning of diversity in diversity. Bhinneka Tunggal Ika is a clear proof of pluralism and clearly illustrates the diversity of the Indonesian people in all aspects. The plurality of the Indonesian people is evident in the many cultures that exist in Indonesia. Social and cultural advances are manifested in the many cultures and religions that exist in Indonesia. For example, Javanese, Sundanese, Batak, and others. In terms of religion, there are Protestants, Muslims, Catholics, Buddhists, Hindus, and Confucians. The Indonesian government officially recognises these six religions (1).

The motto of the Indonesian nation is Bhinneka Tunggal Ika. This phrase comes from Old Javanese and is often translated with the phrase "Different but still one." This motto illustrates clearly the diversity of the Indonesian people in all aspects. Indonesia, in terms of any aspect, is a pluralistic nation. This pluralism is evident in the manifestation of Indonesian culture that is not "one." Indonesian social and cultural pluralism is characterized by a large number of cultures and religions in Indonesia. For

Revised Manuscript Received on April 19, 2019.

Theodorus Pangalila, Pancasila and Civic Education Department, Manado State University, Manado, Indonesia.

Jeane Mantiri, Public Administration Department Manado State University, Manado, Indonesia example, Javanese, Sundanese, Minahasa, Batak, and others. In terms of religion in Indonesia, six religions are officially recognized by the government: Islam, Protestantism, Catholicism, Hinduism, Buddhism, and Confucianism. The structure of Indonesian society is characterised by two unique characteristics. Horizontally, it is characterized by the reality of the existence of social units based on ethnic differences, religious differences, customs, and regional differences. Vertically, the structure of Indonesian society is characterised by the existence of vertical differences between the upper and lower layers, which are quite sharp (2).

Inevitably, Indonesia is indeed a nation consisting of various cultures and customs. Unfortunately, the implementation of the process of community life amid these differences and diversity (ethnicity, culture, race, religion, and the like) is not as easy as what is thought. The shift between different religious groups and ethnic groups, cultures or customs seems to be the trigger for a horizontal division between these different societies. Since 1997 our country has been hit by various kinds of conflicts. Conflicts occur in various regions in Indonesia, for example in Ambon, Papua, Kalimantan, Posso, and in other regions in Indonesia. The conflict between groups in society seems inevitable in various regions of our country. With this conflict many people were killed and killed each other; many people lost their homes because of the destruction of the masses, some were displaced to other islands (1).

Some of the main factors that allow ethnic conflict to surface or become open conflict are: First, changes in the political constellation during the reform era and a climate of upheld freedom are fertile fields to express the concerns of some ethnic groups that have been part of the Indonesian nation. Secondly, the uneven development in various regions in Indonesia was realised or not, polarised based on ethnic groups. The struggle for resources that should be based on healthy competition with universal criteria instead becomes a field of clash of cultural values. At this point, like in the colonial period, economic stratification overlapped with ethnic identity. There is no functional integration among various ethnic groups. Third, it cannot be denied that in Indonesian society, ethnic identity, in this case, ethnicity including cultural values and customs, is still an essential factor in community life, especially in rural areas (3).

In contrast to what happened in various regions in Indonesia that were hit by various horizontal conflicts, the harmony of the people of North Sulawesi was maintained

Published By: 
well; the community remains calm, safe, and peaceful in harmony. North Sulawesi seems without problems, even though the residents of this province are also diverse in ethnicity, religion, race, and language.

In a smaller context, the city of Tomohon shows a harmonious and tolerant life. The people of Tomohon city vary from religion, ethnicity, and language. Although the majority of the people come from the Minahasa tribe, there are also people from other tribes such as Java, Bolaang Mongondow, Sanger, Gorontalo, Totemboan and Chinese, and so on. In terms of religion, the majority of the people of Tomohon city embrace Christianity, but there are also followers of Islam, Buddhism, and Confucianism (4).

The people of the city of Tomohon, live in harmony because of the strong social values of the local culture that are the glue. The principal socio-cultural values in the city of Tomohon are Si Tou Timou Tumou Tou, Mapalus and Torang Samua Basudara. Culture Si Tou Timou Tumou Tou and Mapalus is the most prominent Minahasa culture and animates the lives of the people of North Sulawesi in general and the people of Tomohon in particular. Si Tou Timou Tumou Tou implies that human life must be able to humanise (revive) other people, which is Sam Ratulangi's philosophy. This philosophical thought inspired the life of the Minahasa people and even the entire North Sulawesi community to live in harmony to humanise others and not be enemies of others (homo homini lupus).

Meanwhile, Mapalus is a tribal Minahasa tradition, especially in the context of work where any work or activity is carried out in an atmosphere of cooperation or together (for example in working on the garden). In the more modern Mapalus concept, its application can be seen in religious activities; where when Christians celebrate Christmas or Easter holidays that keep the churches young Muslims. Likewise, when Muslims celebrate the Eid or Eid holidays, those who take care of the surrounding mosques are Christian youth and other Christian organisations. Even in North Sulawesi, there is one institution that has a role in maintaining inter-religious harmony, namely: BKSAUA (Inter-Religious Cooperation Agency). These two cultures in their development combined became the motto of the North Sulawesi people, Torang Samua Basudara (we are all brothers). This motto clearly illustrates how the people of North Sulawesi live in a harmonious, full of brotherhood.

As proof of the tolerance of the people of Tomohon amid differences in 2017, Tomohon obtained a Harmony Award from the Ministry of Religion as a city that has a high level of tolerance. The award was handed over directly by Minister of Religion Lukman Hakim Saiffudin to Mayor Tomohon Jimmy Eman SE Ak. At the 2017 national work meeting at the Mercure Convention Center Jakarta, Sunday (02/26/2017). In 2018 Tomohon was considered as one of the Cities that managed to practice tolerance the best, with a score of 5,833 and for the IKT assessment conducted by SETARA Institute on 94 cities in Indonesia. Tomohon City is in the top ten as the most tolerant city based on the 2018 Tolerant City Index (IKT) announced by SETARA Institute.

The results of preliminary observations indicate that community tolerance in North Sulawesi and especially Tomohon city can be seen concretely in daily life. In the city of Tomohon, there are three large mosques, namely in
Kinilow, in Matani and Kampung Jawa Tomohon, when construction or renovation and rehabilitation is not a problem, because of the City Government, Ministry of Religion and the community support. The participation of Muslims in Tomohon can be seen when there are Christian religious events, for example, at Christmas, Muslims join in guarding the Church and offering hospitality. There are also concrete examples, when there was a Christmas show in 2012 by the Tomohon City Government, Muslims participated in performing the songs and rhythms of Qasidah. Leaders and Muslim religious leaders are always invited to the activities of the City Government and the Ministry of Religion of Tomohon and even every Christian religious event. In shared life, for example in the event of grief, people will flock to help families clean up the funeral home and make tents that will be used in the grief event regardless of the religion and ethnicity of the family overflowing with grief. In an atmosphere of love (for example a wedding) and sorrow, especially when there is a shared meal, food will be separated for people who are Christian and Muslim. In social life, especially in critical religious events, all religious groups will be involved. For example, when Muslims are fasting, there is a joint breaking of the fast between elements of the government and the Muslim community. In Christian church activities, when there are sports and arts activities, representatives from each religion will be invited to participate.

Some of the above prove the mutual understanding between citizens who have different ethnic, cultural, religious and language backgrounds. Until now, there has never been an incident of intolerance, which resulted in conflicts between citizens caused by differences in background. The issue of sanctions for the people who do not show tolerance or intolerance so far has not been there other than moral sanctions, namely isolation from society.

The reality of tolerance between residents and migrants in the city of Tomohon needs to be maintained and developed. The existence of national problems such as the emergence of radicalism that wants to break down Indonesian citizens and society through their intolerant actions towards followers of other religions is undoubtedly a challenge for the sustainability of tolerance in the city of Tomohon. In this case, an effort and intense involvement are needed from all parties, both the government and the people of Tomohon city in maintaining the existence of an atmosphere of tolerance, which is currently well preserved.

Based on the background of the problems that have been described before, then in this study specifically examined about: "the role of the local wisdom of Tomohon community in developing tolerance."

\section{LITERATURE REVIEW}

\section{A. Tolerance}

Discussions about tolerance are currently rife with various instances of intolerance in Indonesia today. In the context of a different Indonesian society, tolerance is a 
necessity. Tolerance comes from the Latin tolerare word, which means "let." Let, in this sense, is an action that does not dispute the differences encountered. In this sense, tolerance is an attitude that is objective, fair, and permissive towards those who discuss opinions, practices, races, religions, nationalities with us, people who are different from us, and free from fanatical attitudes.

Tolerance is an attitude and action that respects differences in religion, ethnicity, ethnicity, opinions, attitudes, and actions of other people who are different from him (5). From the definition above, it can be concluded that the characteristics of tolerance are (a). Respect religious differences, (b). Respect ethnic/ethnic differences, (c). Respect for language differences, (d). Respect differences of opinion, attitudes, and actions. In the results of research on tolerance by Raihani, tolerance is interpreted as patience (acceptance) of difference. In some cases, tolerance is connoted as an attitude of indifference to something that is not liked and often means holding or holding back something that is not liked (6).

Furthermore, according to Ananina \& Danilov, tolerance can be categorized as follows: 1) an expectation of some other kind of behaviour; 2) judging the behaviour as deviant / its interpretation as deviant; 3) the behaviour between others and your behaviour; 4) importance of behavioural peculiarities; 5) ability to influence other people's behavior; 6) somebody else's influence behaviour to your advantage (7). Meanwhile, in his research Endang saw tolerance, in essence, grew in an atmosphere of diversity, especially in the context of religious and cultural diversity in which contained customs, traditions or customs that accompanied it. Therefore, the higher the diversity of a nation, the higher the necessity to develop tolerance values in the lives of individuals and society. With the high tolerance in society, then naturally there will be a harmony of life and harmony and avoid the existence of social tensions or conflicts, there will not even be opposition and hostility between individuals in a society (8).

Another study of tolerance was carried out by Muldoon et al. says that in its most basic form, tolerance requires that an individual who dislikes others or acts of restraint and does not interfere with the person, tolerance can be understood as an act of defending or compromising something that is not liked. Tolerance is a clash of reasons, some of which motivates someone to agree with others and interfere with their actions and some that motivate someone to refrain from interfering even though initially disagree. Someone is tolerant of other people not because of rejection of the person's actions, but rather from the other side, namely as a human being. Thus, the reason that motivates individuals to be tolerant of others is to manage the reasons for fundamental disagreement (9).

\section{B. Local Wisdom}

Etymologically, local wisdom comes from the words wisdom and local. Local means local, local, while wisdom (wisdom) or wisdom. From the definition above, then local wisdom can be interpreted as ideas, values, local culture that are wise, full of wisdom, good value, embedded and followed by members of the community (10). In the anthropological discipline, local wisdom is better known as

a local genius. Local genius is a term first introduced by Quaritch Wales. In Indonesia, this local genius is discussed at length by anthropologists, including Haryati Soebadio who says that local genius is also a cultural identity, identity/personality of the national culture that causes the nation to absorb and cultivate foreign cultures according to their character and abilities (11). Moendardjito in reference (11) says that the element of regional culture is potential as a local genius because it has proven its ability to survive until now. Its characteristics are: (1). Able to defend against external culture, (2). Having the ability to accommodate outside cultural elements, (3). Having the ability to integrate outside cultural elements into indigenous culture, (4). Having a controlling ability (5). Able to give direction to cultural development.

Local genuine is everything that is owned by local people in certain areas, which is a characteristic of the authenticity and distinctiveness of the area without any influence or mixed elements from other regions. In general, local wisdom can be divided into two, namely local wisdom that can be seen with the eye (tangible) such as cultural objects historical, cultural heritage and religious activities; and local wisdom that cannot be seen by the eye (intangible) in the form of value or meaning of an object or cultural activity.

Wisdom or wisdom can be understood as a collective understanding, knowledge, and wisdom that influences a decision to resolve or overcome a life problem. Wisdom, in this case, is an embodiment of a set of understandings and knowledge that undergoes a developmental process by a group of local communities or communities gathered from a process and long experience in interacting in a system and the bond of mutually beneficial relationships (12).

From some of the meanings of local wisdom above, it can be said that local wisdom is the basis or benchmark for the government and the community in making decisions at the regional level in various fields including education and processing of natural resources. The wisdom of local culture is thus local knowledge that has long existed in the community and has been integrated with the system of beliefs, norms, and culture and expressed in the traditions and myths that have been adhered to for a long time and survived the exposure of foreign cultures. The function of local wisdom is as follows: (1). Serves for the conservation and preservation of natural resources, (2). Serves for the development of human resources, (3). Serves for the development of culture and science, (4). Serves as advice, trust, literature, and taboos, (5). Social meaning such as the communal integration ceremony/relatives, (6). Cultural meaning, for example, at the agricultural cycle ceremony, (7). Meaningful ethics and morals, (8). Meaningful politics, for example, the ceremony of the bowl and the power of the patron-client (13).

Based on some of the meanings and functions of local wisdom above, it can be concluded that local wisdom is the culture of the local community that has survived in the community's real life and is used as a benchmark for acting and behaving. Local wisdom has become cultural values that 
become the glue and at the same time, become the identity of the community in which they are located. The following is the local wisdom of the people of North Sulawesi, especially the city of Tomohon.

Si Tou Timou Tumou Tou. The concept of Si Tou Timou Tumou Tou is a cultural value of the people of North Sulawesi and specifically the Minahasa people who are inherited from generation to generation. In this concept contained the fundamental values in life that can function as a driver, controlling life, both in maintaining existence and survival and for the development of himself. Therefore according to Tilaar (1998:11), the expression Si Tou Timou Титои Тои is an excellent concept. The excellence of this concept by Tilaar is summarised as follows: First, the concept was born from the Minahasa culture, which shows the nature of dynamics. Life is not static. Man becomes. Humans are a process that becomes something. The Minahasa tou must be "Si Tou Minahasa." Between "the tou" and "Tou" there is an existential difference. Second, the concept contains the levels of the vitality of the Minahasa people. Minahasa culture and society have a strong impulse of life because they do not know the boundaries of social barriers as in the social structure of feudalism. Fourth, the concept as described above, that human life is not just life but leads to something: A teleological concept. Fifth, the dynamic and futuristic-teleological concept has a global direction, meaning realistic. "The tou timou" is not just a life, it grows, or "tumou" becomes "tou" or a real realistic person. Sixth, the concept refers to a whole human concept or an intergalactic concept about humans. Seventh, the concept of "Si Tou Timou Tumou Tou," besides being an intergalactic concept, also does not merge individual values in anonymous togetherness. Eighth, this concept implies that in the process of becoming Minahasa Man, it is a process of Minahasa in Minahasa culture. The me-Minahasa process does not occur in empty spaces but within the scope of Minahasa culture.

Mapalus. Mapalus is a system or collaboration technique for the common interest in Minahasa / North Sulawesi culture. According to reference (14), Mapalus is a system of community life in various fields of life, as an actualisation of the nature of human beings as creatures of shared, godly, and obedient work on the values system of society. Fundamentally, Mapalus is a form of traditional cooperation that has differences with other forms of cooperation, for example, associations or business associations. Mapalus is not just a "cooperation" (cooperation) that cooperates for a little interest, but rather a whole life of "working togetherness" in the fields of economy, culture, organisation, and management of joint work, society, religion, defence, and security. Philosophically, Mapalus contains original meanings and meanings. Mapalus as the Local Spirit and Local Wisdom of the Minahasa / North Sulawesi community which is engraved and correlated in it: 3 (three) types of essential human nature in the group, namely: Touching Hearts, Teaching Mind, and Transforming Life. Mapalus is the essential nature and activities of life of Minahasa / North Sulawesi people who are called with a fundamental and profound conscience (touching hearts) with full awareness and responsibility to make people and their groups (teaching mind) to turn on and prosper each person and group in transforming a community. As a working system, it has ethos values such as reciprocal ethos, participatory ethos, solidarity, responsibility, cooperation, ethical leadership, discipline, transparency, equality and trust (15).

Torang Samua Basudara. Torang Samua Basudara is a motto that was initiated by a national figure from Sulut E. E. Mangindaan when he served as Governor of North Sulawesi Province. The motto of Torang Samua Basudara has long grown and developed as a cultural value of the people of North Sulawesi. This motto is lived and fully implemented by the residents of Nyiur Melambai / North Sulawesi so that it becomes steady local wisdom and an antidote to various potential conflicts, especially the social conflict in 19982000. Torang Samua Basudara has become a famous slogan on Bumi Nyiur Melambai / North Sulawesi. This slogan is not just an empty slogan but has become a part of life for the people of North Sulawesi. This is evident from the conduciveness of security, harmony, and harmony of the people of North Sulawesi. The principle of Torang Samua Basudara becomes the identity of the people of North Sulawesi, which has slowly become a national and international concern (16).

The principle of Torang Samua Basudara puts forward the supremacy of tolerance, which is the most basic foundation for creating harmony and harmony in society. The North Sulawesi community is a multi-dimensional society that is formed from a variety of different beliefs, ethnicities, and cultures. Humans as social beings have patterns, and different characteristics according to their level of education, association, and experience - various experiences, education, culture shape the character of each person. Imposing our tastes on others is impossible. What is possible is that each person adjusts to others (16).

\section{METHODOLOGY}

This study is qualitative research with descriptive and analytical approaches that highlight the importance of examining and analysing the life of a phenomenon or appearance of what is happening in a stream of consciousness. This is usually done by systematically collecting and analysing historical materials using methods that ensure the credibility of both the data and the results. This approach is more concerned in-depth observation and interview techniques become very important in data collection, and researchers become the main instrument. The use of qualitative descriptive approach because it is suitable for the problems studied, and also because: (1) the approach in this study is more flexible, (2) able to present the data directly, the nature of the relationship between the informant and the researcher, (3) can adapt and be sensitive to the phenomena encountered in the field. This research was conducted in Tomohon City-North Sulawesi. The reason for choosing this area because Tomohon city is quite famous as a city of full tolerance. The majority of the people of Tomohon are from Minahasa group with Christian as their primary religion. The local interactions embrace the 
harmony among immigrants and the local community. This research utilises grounded theory as the primary research method. Grounded theory is a theory obtained from phenomena study which represents the research itself. It is also defined that there are three kinds of data analysis in a coding process: Open Coding, Axial Coding, and Selective Coding (17). This research also uses several kinds of validity test in process analysis. First, internal validity or credibility is applied for the aspect of truth, the external validity of transferability for the method application, dependability for the aspect of consistency, and confirmability for the aspect of neutrality (18).

\section{RESULTS AND FINDINGS}

\section{A. Si Tou Timou Tumou Tou}

Si Tou Timou Tumou Tou is a culture, belief, concept, an idea that is a guide in making choices when thinking about something and acting about something inappropriate and appropriate. The values contained in the culture of Si Tou Timou Tumou Tou have encouraged all North Sulawesi people to be tolerant of people of different religious, ethnic, racial, cultural and linguistic backgrounds $(1,16)$.

Si Tou Timou Tumou Tou means that in everyday life the essence of human life is the process of humanizing other people into full human beings. This culture is a rational expression of the Minahasa people especially since Christianity entered the Land of Minahasa, then was intellectually reappointed by Sam Ratulangi. Based on the results of the interview, it was revealed that the expression of Si Tou Timou Tumou Tou was indeed reflected in the search for the lives of the people of Tomohon who were open and socialized without discriminating against other people's ethnic and religious backgrounds. From a historical perspective, this expression is the philosophy of the Minahasa community and becomes the local wisdom of the people of North Sulawesi in general. Wisdom or wisdom is a collective meaning, wisdom, and knowledge that affect overcoming problems in life and influencing a settlement decision (1). Wisdom here is the embodiment of the elements of knowledge and understanding of a community community or group of people through prolonged interactions gathered as a result of long processes and experiences and in which there are a system and even mutual relations (12). Therefore as local wisdom, this expression has become the basis of the thinking of the people of Tomohon and Minahasa people in general. Since childhood, children have educated and inspired the expression of the tou timou tumou tou, and this has been carried on until they are significant. Moreover, in a sense, this expression is "muntep" / ingrained in the lives of the people of the city of Tomohon and the Minahasa community in general.

Based on the narrators' information, it was revealed that Si Tou Timou Tumou Tou by the Minahasa community and Tomohon, in particular, was seen as a belief, idea, and concept about what was feasible and not feasible in their lives. Si Tои Tітои Tитои Tou contains fundamental values that have encouraged the Tomohon community to be tolerant of people of different religious, ethnic, racial, group that experiences a process of development, in this

cultural and linguistic backgrounds.

The findings of this study reinforce the opinion of reference (19) who said that culture is: "a historically transmitted pattern of meanings embodied in symbols, a system of inherited conceptions of expressions in forms of means which communicate, perpetuate, and develop their knowledge about and their attitudes toward life." Geertz explained that culture is "a pattern of historical transmission of meanings included in symbols or a system of conception that is presented and inherited in the way humans communicate, that is in the form of symbols, develop and preserve the knowledge they have and how they respond life. "Based on his definition of culture, Geertz wanted to emphasise that culture is an actual and constitutive dimension of social life rather than just a guarantee mechanism for social integration. Geertz sees culture as a "symbolic arch" or "blueprint" by which one can create their world that is meaningful in two levels at once: emotional and cognitive (20).

\section{B. Mapalus}

For Minahasans, Mapalus is a collective term. They associate it with a form of activities which character and purpose is to help others. This help, of course, must be given according to a specific procedure. However, such a mutual help institution is not unique to the Minahasans; every ethnic group in Indonesia, and indeed throughout the world, probably possesses its version (21). Mapalus is the dominant culture of the people of North Sulawesi. Mapalus, in a real sense, means the form of cooperation or cooperation in working on a job. The term Mapalus itself is a combination of the words ma (mutually) and palus (pouring, spilling). So, etymologically, Mapalus means spilling each other or pouring each other. The concept of "Si Tou Timou Tumou Tou" in the reality of the life of Minahasa / North Sulawesi people, from the beginning, has grown and developed in the form of the work ethic of Mapalus or Maendo (Tountemboan Language). In this context, Mapalus can be seen as a form of concrete actualisation dealing with the most profound meaning of "Si Tou Timou Tumou Tou." Mapalus cultural values in practice can be seen from the four principles of actualisation, namely deliberation and consensus, family, religion, and cooperation), and five aspects of the Mapalus principle of life, namely: openness, help, togetherness, group discipline, and usefulness. Mapalus is like cooperation or copying help with each other. The Mapalus value here is well implemented and causes the soul to help each other that is deeply embedded in the Tomohon community. Mapalus is very influential on the way of thinking and acting of the people of the city of Tomohon and has even been rooted and ingrained which manifested itself in social activities such as the harmony of the village, harmony among the people, and others. The value of this Mapalus culture in the culture of the Minahasa Mapalus is something that has been maintained until now. Mapalus values are so thick in everyday life, for example, the spirit of mutual help, gathered together in the harmony 
of clans and another social harmony. Mapalus is a system of values for people's lives that are actualized in various aspects of human life as an act of human nature as working beings. It is this Mapalus value that makes the Minahasa people and Tomohon people, in particular, so tolerant of immigrants. This is in line with the opinion of Edward B. Tylor (1871) as quoted by reference (22) who said that culture or civilization is a complex totality of beliefs, art, knowledge, customs, laws, and habits and other skills acquired by humans in their essence as part of a society.

Mapalus is also a form of local wisdom of the people of North Sulawesi, especially Minahasa and Tomohon. Mapalus has long been a grip on the community in thinking, acting and behaving amid differences in society. A Mapalus culture that has the essence of togetherness. In a manner general, this Mapalus culture as the implementation of development activities which is driven by a desire to meet needs together with how to work together in full understanding and harmonious spirit to maintain because it is realised all of that is the result of joint work (23).

\section{Torang Samua Basudara}

Torang Samua Basudara is a motto that was initiated by a national figure from Sulut E. E. Mangindaan when he served as Governor of North Sulawesi Province. Mapalus is a Mutual Cooperation with the basis of Cooperation. In general, Mapalus is a form of assisting collaboration help among several people in the village in the form of one group to do work in turns (24). The motto of Torang Samua Basudara has grown and developed for a long time and has become the principal value and culture for the people of North Sulawesi. Torang Samua Basudara as a motto has been implemented and lived in real life of the Nyiur Melambai / North Sulawesi community. Even this slogan has been widely recognised as a reliable and robust local wisdom and even an antidote to various threats of conflict, especially when in Indonesia in the 1998-2002 period, there were social conflicts. Torang Samua Basudara has become a prevalent slogan on Bumi Nyiur Melambai / North Sulawesi. This slogan is not just an empty slogan but has become a part of life for the people of North Sulawesi. This is evident from the conduciveness of security, harmony, and harmony of the people of North Sulawesi. The principle of Torang Samua Basudara becomes the identity of the people of North Sulawesi, which has slowly become a concern nationally and internationally. In connection with the value of Torang Samua Basudara culture, it is so thick in the lives of the people of Tomohon. This cultural value is also very well maintained and animates the lives of the people of North Sulawesi in general and Tomohon city in particular. This motto emerged when the government of North Sulawesi at that time Mr. E. E. Mangindaan served as Governor, aware of the danger of SARA conflict because North Sulawesi was a place of refuge for victims of riot Ambon, Ternate, Posso. Therefore, starting from that moment began to be echoed by the slogan Torang Samua Basudara as an adhesive for the people of North Sulawesi.

The cultural value of Torang Saтиa Basudara is very well maintained and animates the life of the people of Tomohon city. This life principle is a necessary capital for the creation of tolerance of the people of Tomohon city towards immigrant communities of different religions and tribes. Torang Samua Basudara becomes the fundamental essence of tolerance in religious communities, especially in the creation of harmonious and harmonious people's lives. The people of North Sulawesi are a multicultural society formed by the existence of different cultures, tribes, beliefs, and religions. Differences in experience and association, nature, castings, and level of education are the most basic nature of humans as social beings. The character of every human being is formed because of cultural differences, education and life experiences. Self-conformity in society is a wiser thing than imposing our will on others. This opinion is in line with what was said by reference (25) which says that culture is closely related to groups of individuals, especially verbal behaviour that is learned from generation to generation. How certain groups distinguish themselves from other groups and how individuals act in specific situations. That is, "culture" reflects words and general behaviours that are learned from specific cultural contexts and environments continuously both caused by actions or objects (stimuli), which are defined as specific contexts.

The cultural value of Torang Samua Basudara is a unifying tool and guardian of the harmony of the life of the people of North Sulawesi. In other words, Torang Samua Basudara has become a social capital for the people of North Sulawesi and Tomohon in particular. This fact is in line with the theory of social capital which, according to him, is a level of cultural integrity in a community or society. He refers to processes between people who build networks, norms, and social trust and facilitate coordination and mutually beneficial cooperation. Furthermore, reference (26) understands that social capital is a resource or source produced by the existence of communication and interaction between individuals who are members of a community or community. However, in reality, measurements of interactions are rarely involved in measuring social capital. Here the maintenance and creation of trust between citizens of a society is the result of their daily interactions. An interaction can take place in a specific context or institution (institutional). In a specific context, the occurrence of an interaction that gives birth to an emotional bond as a result of a deep relationship between individuals in the community. In the institutional context, interactions can arise when the organization and vision of an organization have similarities with the goals and vision of other groups or organizations. Therefore, the fact is that when other regions around North Sulawesi (SULUT) were emotionally burned to the conflict in the name of religion, it turned out that SULUT was difficult to ignite and live in harmony.

\section{CONCLUSION}

The local wisdom of the Tou Timou Tumou Tou, Mapalus, and Torang Samua Basudara has become fundamental values that play an essential role in the formation of tolerance of the people of Tomohon city. These three local pearls of wisdom have merged and become a part of the life of the people of Tomohon city. 


\section{ACKNOWLEDGMENT}

This research was funded by the Indonesian Ministry of Research, Technology and Higher Education in the 2019 budget year.

\section{REFERENCES}

1. Pangalila T, Ngarawula B, Sadhana K, Lonto AL, Pasandaran S. Local wisdom si tou timou tumou tou in forming tolerance of Tomohon city people of North Sulawesi. In: 1st International Conference on Social Sciences (ICSS 2018) [Internet]. Atlantis Press; 2018. p. 811-4. Available from: https://www.atlantispress.com/proceedings/icss-18/25903914

2. Nasikun J. Sistem sosial Indonesia. Yogyakarta: Universitas Gajah Mada Press; 2011.

3. Wirutomo P. Sistem sosial Indonesia. Jakarta: Penerbit Universitas Indonesia; 2011.

4. Pangalila T, Ngarawula B, Sadhana K. Tolerance behavior among society in city of Tomohon, North Sulawesi. Int $\mathbf{J}$ Humanit Soc Sci Res [Internet] 2018;4(4):46-9. Available from: http://www.socialsciencejournal.in/archives/2018/vol4/is sue4

5. Badan Penelitian dan Pengembangan Kurikulum. Pengembangan Pendidikan Budaya dan Karakter Bangsa [Internet]. Jakarta: Kementerian Pendidikan Nasional Badan Penelitian dan Pengembangan Kurikulum; 2010. 112 p. Available from: http://faterna.ilearn.unand.ac.id/

6. Raihani. A whole-school approach: A proposal for education for tolerance in Indonesia. Theory Res Educ. 2011;9(1):23-39.

7. Ananina V, Danilov D. Ethnic tolerance formation among students of Russian Universities: current state, problems, and perspectives. Procedia-Social Behav Sci. 2015;214:487-96.

8. Endang B. Mengembangkan sikap toleransi dan kebersamaan di kalangan siswa. J Visi Ilmu Pendidik [Internet]. 2009;1(2):89-105. Available from: http://jurnal.untan.ac.id/index.php/jvip/article/view/54

9. Ryan Muldoon, Michael Borgida MC. The conditions of tolerance. Polit Philos Econ. 2011;11(3):322-344.

10. Syamsiar C. Bentuk-bentuk kearifan lokal dalam kehidupan masyarakat Indonesia sebagai sumber gagasan berkarya seni rupa. J ISI Surakarta [Internet]. 2010;2(1):1-6. Available from: http://jurnal.isiska.ac.id/index.php/brikolase/article/view/414

11. Ayatrohaedi. Kepribadian budaya bangsa (local genius). Jakarta: Pustaka Pelajar; 1986.

12. Marfai MA. Pengantar etika lingkungan dan Kearifan lokal. Yogyakarta: Gadjah Mada University Press; 2012.

13. Sartini. Menggali kearifan lokal nusantara sebuah kajian filsafati. J Filsafat [Internet]. 2004;37(2):11-130. Available from: https://jurnal.ugm.ac.id/wisdom/article/view/33910/2026 2

14. Turang J. profil kebudayaan Minahasa. Tomohon: Majelis Kebudayaan Minahasa; 1997.

15. Umbas V. Mapalus: gagasan dan ajaran [Internet]. 2011. Available

from: http://cahyasiangwilsonlumi.wordpress.com/2011/01/13/ mapalus-gagasan-ajaran/

16. Pangalila T. Pengaruh internalisasi nilai budaya $\mathrm{Si}$ Tou Timou Tumou Tou, Mapalus dan Torang Samua Basudara Dalam Pembelajaran PKn Terhadap Peningkatan Sikap Toleransi Siswa: Penelitian Survey Terhadap Siswa SMA di Kota Tomohon-Sulawesi Utara. [Bandung]: Universitas Pendidikan Indonesia; 2013.
17. Strauss A, Corbin J. Dasar-dasar penelitian kualitatif Muttaqien MS\& I, editor. Yogyakarta: Pustaka Pelajar; 2003.

18. Sugiyono. Metode penelitian uantitatif, kualitatif dan R\&D. Bandung: Alfabeta; 2011.

19. Geertz C. Common sense as a cultural system. Antioch Rev. 1975;33(1):5-26.

20. Sutrisno M, Putranto H. Teori-Teori Kebudayaan. Jakarta: Kanisius; 2005.

21. Parengkuan FEW. A Contribution To The History Of Mapalus In The Minahasa, North Sulawesi. J Masy dan Budaya, [Internet]. 2006;8(2):1-18. Available from: http://jmb.lipi.go.id/index.php/jmb/article/view/186/166

22. Munch R, Smelser NJ. Theory of Culture. California: University of California Press; 1992.

23. Mulyawan R. Penerapan Budaya Mapalus Dalam Penyelenggaraan Pemerintahan Di Kabupaten Minahasa Provinsi Sulawesi Utara. CosmoGov. 2017;1(1):35.

24. Uada H, Kandwangko N, Goni SYVI. Budaya Mapalus dalam Meningkatkan Aktivitas Kelompok Tani (Suatu Studi di Desa Talawaan Atas Kecamatan Wori Kabupaten Minahasa Utara). Holistik [Internet]. 2017;10(20):1-17. Available from: https://ejournal.unsrat.ac.id/index.php/holistik/article/vie w/17555

25. Fallon LM, O'Keeffe B V, Sugai G. Consideration of culture and context in school-wide positive behavior support: A review of current literature. J Posit Behav Interv [Internet]. 2012;14(4):209-19. Available from: http://pbi.sagepub.com/content/14/4/209 [03

26. Suharto E. Modal Sosial dan Kebijakan Publik [Internet] 2016 [cited 2017 Jan 14]. Available from: www.policy.hu/suharto/.../MODAL_SOSIAL_DAN_KE BIJAKAN_SOSIA.pdf

\section{AUTHORS PROFILE}

First Author Theodorus Pangalila is a lecturer in the Department of Pancasila and Civic Education, Faculty of Social Sciences, Manado State University. Bachelor of Philosophy Education from the Philosophy College of Pineleng Seminar, Masters in Citizenship Education from the Indonesian University of Education Bandung and Doctor of Social Sciences from Merdeka University Malang. The author actively examines the learning of citizenship education especially concerning the topic of sociology of citizenship.

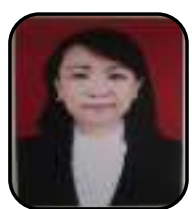

Second Author Jeane Mantiri is a lecture in the Department of Public Administration, Faculty of Socia Science, Manado State University. Bachelor of Public Administration and Masters in Public Administration The author actively examines the topic of public policy. 